\title{
Pathogen Biocontrol Using Plant Growth-Promoting Bacteria (PGPR): Role of Bacterial Diversity
}

\author{
Hao Wang ${ }^{1,2}\left(\right.$, Runjin Liu ${ }^{3}$, Ming Pei You ${ }^{4}$, Martin J. Barbetti ${ }^{4}$ and Yinglong Chen ${ }^{4, * \mathbb{C}}$ \\ 1 State Key Laboratory of Soil Erosion and Dryland Farming on the Loess Plateau, Research Center of Soil and \\ Water Conservation and Ecological Environment, Chinese Academy of Sciences, Xianyang 712100, China; \\ hao_wang@nwafu.edu.cn \\ 2 University of Chinese Academy of Sciences, Beijing 100049, China \\ 3 Institute of Mycorrhizal Biotechnology, Qingdao Agricultural University, Qingdao 266109, China; \\ liurj@qau.edu.cn \\ 4 The UWA Institute of Agriculture, and School of Agriculture and Environment, The University of Western \\ Australia, LB 5005, Perth, WA 6009, Australia; mingpei.you@uwa.edu.au (M.P.Y.); \\ martin.barbetti@uwa.edu.au (M.J.B.) \\ * Correspondence: yinglong.chen@uwa.edu.au
}

Citation: Wang, H.; Liu, R.; You, M.P.; Barbetti, M.J.; Chen, Y. Pathogen Biocontrol Using Plant Growth-Promoting Bacteria (PGPR): Role of Bacterial Diversity. Microorganisms 2021, 9, 1988. https://doi.org/10.3390/ microorganisms 9091988

Academic Editor: Volker Brozel

Received: 22 August 2021

Accepted: 15 September 2021

Published: 18 September 2021

Publisher's Note: MDPI stays neutral with regard to jurisdictional claims in published maps and institutional affiliations.

Copyright: (c) 2021 by the authors. Licensee MDPI, Basel, Switzerland. This article is an open access article distributed under the terms and conditions of the Creative Commons Attribution (CC BY) license (https:// creativecommons.org/licenses/by/ $4.0 /)$.

\begin{abstract}
A vast microbial community inhabits in the rhizosphere, among which, specialized bacteria known as Plant Growth-Promoting Rhizobacteria (PGPR) confer benefits to host plants including growth promotion and disease suppression. PGPR taxa vary in the ways whereby they curtail the negative effects of invading plant pathogens. However, a cumulative or synergistic effect does not always ensue when a bacterial consortium is used. In this review, we reassess the disease-suppressive mechanisms of PGPR and present explanations and illustrations for functional diversity and/or stability among PGPR taxa regarding these mechanisms. We also provide evidence of benefits when PGPR mixtures, rather than individuals, are used for protecting crops from various diseases, and underscore the critical determinant factors for successful use of PGPR mixtures. Then, we evaluate the challenges of and limitations to achieving the desired outcomes from strain/species-rich bacterial assemblages, particularly in relation to their role for plant disease management. In addition, towards locating additive or synergistic outcomes, we highlight why and how the benefits conferred need to be categorized and quantified when different strains/species of PGPR are used in combinations. Finally, we highlight the critical approaches needed for developing PGPR mixtures with improved efficacy and stability as biocontrols for utilization in agricultural fields.
\end{abstract}

Keywords: rhizosphere; bacterial mixture; compatible strains; plant defense; disease control; sustainable agriculture

\section{Introduction}

In the rhizosphere micro-habitat, plants continuously interact with a plethora of microbes, including bacteria, fungi and viruses [1]. Interactions between beneficial microbes and pathogens are of great significance in plant health and growth and thus have received substantial attention [2-4]. However, most research has focused solely on the relationship between a single pair of interacting species, (i.e., one pathogen and one antagonist), ignoring the immense microbial diversities within these functional communities coexisting around or in plant roots. Hence, such studies largely do not relate to natural soil conditions and are inconsistent with the view that diverse species operate in microbial communities [5].

Plant Growth-Promoting Rhizobacteria (PGPR) represent a diverse category of microbes associated with many plant species and bringing benefits to plants, such as growth promotion and stress alleviation. There is a large body of literature demonstrating the potential use of PGPR as biological control agents and for replacing chemical fertilizers and 
pesticides/fungicides [6-8]. The most commonly studied bacteria in relation to biocontrol are members of the genera Pseudomonas, Bacillus, Azospirillum, and Streptomyces [2,8,9]. Multiple mechanisms of action have been postulated as to how this defense arises, including direct competition for nutrients and niches, antibiosis, enzyme lysis, signal interference and indirect induction of host resistance $[7,8,10-12]$. The accumulated evidence suggests PGPR taxa vary in the expression of traits [13-15] that correlate with one or more of the above mechanisms, thereby altering their capacities for protecting host plant from pathogens and thus promoting plant growth. Since PGPR live in communities on the root surface or sometimes inside the root (i.e., endophytes) and they are recruited by host plants, it has been deemed that each bacterial 'component' offers specific benefits for plants [16]. Therefore, there is a critical need to better understand such situations in terms of multi-species PGPR assemblages to maximize desired benefits to plants, particularly under the conditions of pathogen challenges. This review focuses on critical issues concerning PGPR-mediated disease suppression, especially the mechanisms of disease suppression by PGPR mixtures, the efficacy and limitations of PGPR mixtures on biological control, and the determinant factors for successful use of different species/strains of PGPR in mixtures.

\section{Mechanisms of PGPR in Disease Suppression}

\subsection{Competitive Rhizosphere Colonization}

The variable and inadequate biocontrol of PGPR in field tests has usually been correlated with their poor rhizosphere colonization $[17,18]$. Bacterial inoculants must establish themselves in the plant rhizosphere at population density levels sufficient and persistent enough to generate plant beneficial effects, such as disease suppression. This is dependent upon the ability of bacterial inoculants to proliferate and efficiently colonize the root system, which is well-recognized as the limiting step for biocontrol [19]. Plants exude organic nutrients to the root surface and rhizosphere, among which various nutrients provide niches attracting a diverse range of microorganisms, including pathogens (Figure 1). The common metabolites from root exudates consist of sugars, amino acids, organic acids, vitamins, nucleosides, phytosiderophores, and phenolic compounds [20], and simultaneously, they function as chemical signals for motile bacteria to migrate towards the root surface [21]. PGPR are differentiated to sense these chemo-attractants during root colonization. Examples include the chemotactic responses of Corynebacterium flavescens and Bacillus pumilus induced by rice root exudates, which were stronger than those of other bacteria [22], and Azospirillum strains that show varying degrees of attraction and/or chemotaxis to organic acids, sugars, and amino acids [23]. Recently de Souza et al., (2019) using comparative genomic analysis, found that growth-promoting traits of PGPR involving carbon and nitrogen acquisition, rather than other traits such as auxin production, are deterministic for their successful colonization and population establishment in the rhizosphere [24]. The components and quantities of compounds exuded by plant roots are determined by the genetic constitution of particular plant types and by environmental factors [25]. This implies that PGPR colonization and/or competence is not only closely connected with their capacities to avail of a specific environment and to adapt to changing conditions, but also connected with their capacities to operate as diversified nutrient uptake phenotypes in PGPR. 
(a)

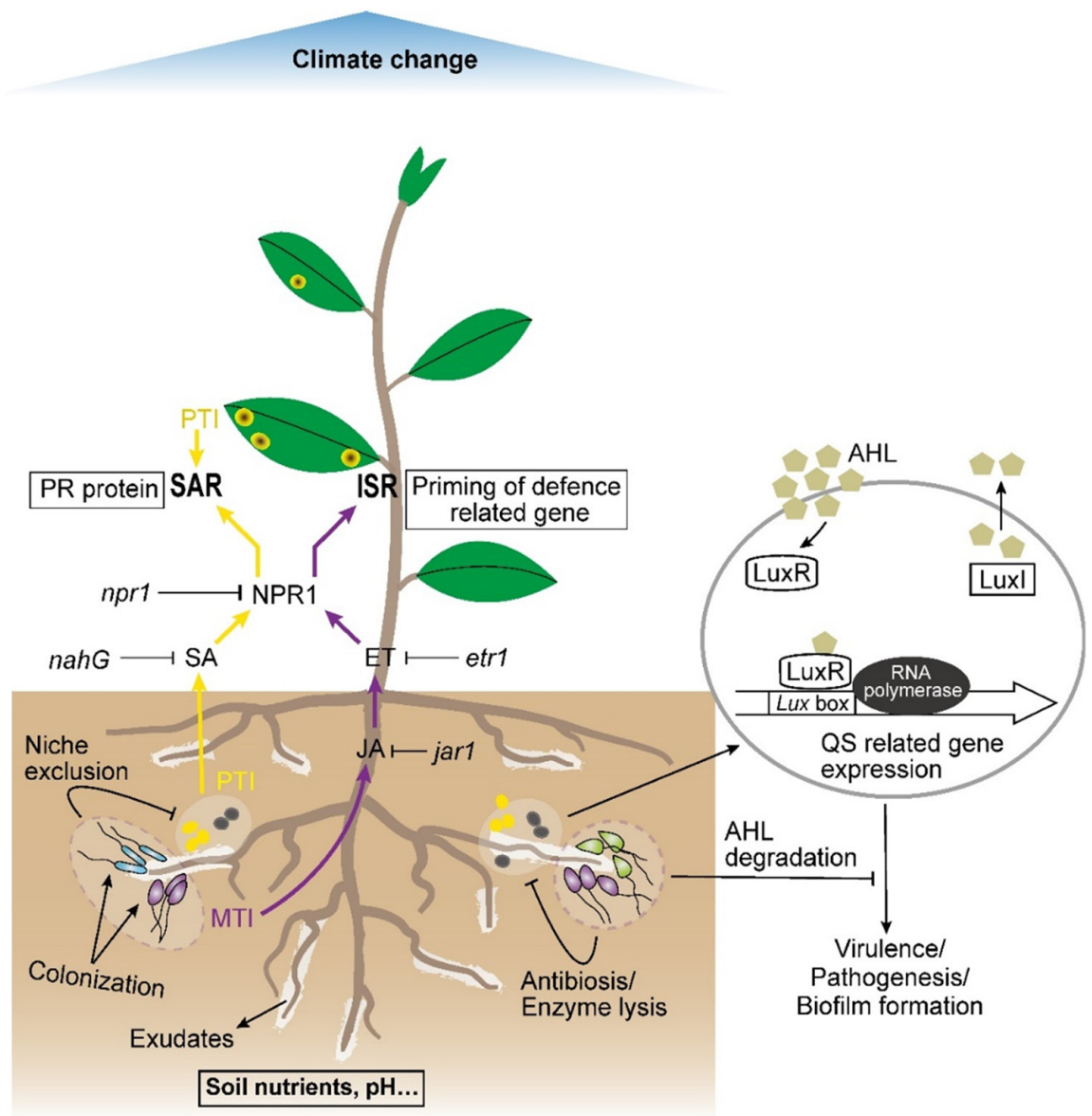

(b)

\begin{tabular}{|c|c|}
\hline $\begin{array}{l}\text { Outcome for } \\
\text { hosts }\end{array}$ & Interaction mechanisms \\
\hline \multirow{2}{*}{$\begin{array}{l}\text { Synergistic } \\
\qquad(++)\end{array}$} & Traits of different PGPR for disease suppression are complementary \\
\hline & $\begin{array}{l}\text { The exertion of disease-suppressive traits by one PGPR depends on other } \\
\text { PGPR }\end{array}$ \\
\hline $\begin{array}{l}\text { Additive (or } \\
\text { cumulative) } \\
\qquad(+)\end{array}$ & $\begin{array}{l}\text { Disease-suppressive traits from different PGPR are independent and are not } \\
\text { interactive }\end{array}$ \\
\hline \multirow{2}{*}{$\begin{array}{l}\text { Antagonistic } \\
\qquad(-)\end{array}$} & $\begin{array}{l}\text { Competition for access to host provided nutrients/niches among introduced } \\
\text { PGPR and/or between PGPR and indigenous microbes leads to declined } \\
\text { rhizosphere establishment and ineffective disease control }\end{array}$ \\
\hline & $\begin{array}{l}\text { The effect of mechanism of action by one PGPR negatively affected the } \\
\text { development of or the exertion of disease-suppressive traits by other PGPR }\end{array}$ \\
\hline
\end{tabular}

Figure 1. (a) The introduced multi-species PGPR assemblages (represented in blue, purple, and light green) and their diverse biocontrol mechanisms in protecting plants against different pathogens (represented in dark grey and yellow or their blend) present in rhizosphere soil or aboveground plant parts. PTI/MTI, pathogen-/microbe-triggered immunity; QS, quorum sensing; AHL, $\mathrm{N}$-acylhomoserine lactone; SA, salicylic acid; JA, jasmonic acid; ET, ethylene; SAR, systemic acquired resistance; ISR, induced systemic resistance; NPR, nonexpresser of pathogenesis-related (PR) genes; LuxI, AHL synthase; LuxR, AHL regulator. (b) This table describes a set of interaction mechanisms between PGPR that could create the likely outcomes (synergistic, additive, or antagonistic) for the host plants. 
Nutrients and physical sites are crucial for the establishment of populations of epiphytic microorganisms, including pathogens and nonpathogens alike. Competition for nutrients and for occupation of niches at root surfaces is an indirect but important antagonism by PGPR against pathogens that depend on such external resources [26]. For example, in the rhizospheres of different crops, certain bacterial strains inhibit oospore germination of Pythium aphanidermatum by competing for glucose and asparagine [27], and Pseudomonas fluorescens PJ0210 competes for glucose with the pathogen Bipolaris maydis, the causal agent of leaf blight in corn [28]. An extraordinary form of nutrient competition is limitation by iron. Normally in aerobic soil, iron is present in insoluble forms (i.e., III) that are barely or non-accessible for many living organisms. However, under conditions of iron deficiency, PGPR have evolved to acquire ferric iron through the production of low-molecular-weight compounds known as siderophores [29], allowing solubilization of iron and its access from mineral or organic complexes. Thus, siderophore production by PGPR gives them competitive advantages in colonizing roots and in excluding pathogenic microbes from rhizosphere ecological sites [30]. Different categories of bacterial siderophores have been identified and mainly include hydroxamates, carboxylates, and catecholates [31], and they show varied abilities to sequestrate iron in vitro. In general, they have higher affinity for ferric iron, particularly those produced by fluorescent Pseudomonas, compared to the fungal siderophores $[29,32]$. Deprivation of ferric iron by P. putida-producing siderophores mediates suppressiveness to Fusarium wilt pathogens of cucumber, radish, and flax [32]. Fluorescent Pseudomonas EM85 and Bacillus spp. [MR-11(2) and MRF] isolated from maize rhizosphere, produce siderophores that suppress root rot disease [33]. Siderophore production by P. fluorescens 3551 or P. putida N1R contributes to its antagonistic activity against P. ultimum $[34,35]$. Similarly, fluorescent Pseudomonas secreting the siderophore pyoverdine induces suppression of the fungal pathogen Botrytis cinerea by depleting iron [36]. Sneh et al. (1984) demonstrated that both chlamydospore germination and mycelia growth of Fusarium oxysporum were suppressed more by siderophore-producing P. fluorescens than other isolates [37]. Some Pseudomonas strains are even able to utilize heterologous siderophores secreted by root-colonizing pathogenic microorganisms [38,39].

Mutants defective in motility are significantly less competitive for root colonization and therefore not capable of controlling fungal root pathogens, and vice versa [40,41]. Additionally, other studies have indicated that biofilm formation is also a determinant in rhizosphere colonization by PGPR, such as where mutants unable to synthesize exopolysaccharide were unable to form biofilms and efficiently colonize the rhizosphere, and thus rendering low population levels attached to the rhizosphere [42,43]. Moreover, using RNA sequencing, Guo et al. (2020) proved that Streptomyces pactum Act12 inoculation enhanced tomato rhizosphere colonization and competition by indigenous $P$. koreensis GS via the promotion of swimming motility, biofilm formation, and environmental adaptation [44].

From a microorganism perspective, the nutrient niches in the rhizosphere soil are frequently limited. Increasing the richness of PGPR taxa (and thus functional diversity) colonizing the rhizosphere, and their ability to do so across a wider range of biotic and abiotic conditions, would likely ensure greater rhizosphere competence. In addition, importantly, it should also improve their ability to outcompete pathogens for limited resources available and so making them unavailable for pathogenic microbes to acquire and develop.

\subsection{Antibiosis}

Toxins that kill other organisms at low concentrations $(<10 \mathrm{ppm})$ are termed antibiotics [45]. Antibiotics comprise a heterogeneous group of low molecular weight, organic compounds [46], which interfere with the synthesis of pathogen cell walls, cell membrane structures, and the biogenesis of initiation complexes on the smaller subunit of the ribosome [47]. Accumulated reports on antibiotic-mediated pathogen suppression mainly include Pseudomonas spp. producing 2,4-diacetylphloroglucinol (DAPG) [48-51], phenazine ([52-54], pyoluteorin [55-57], pyrrolnitrin [58-60], hydrogen cyanide (HCN) [61,62], and 
Bacillus spp. producing bacillomycin D [63,64], mycosubtilin [65-67], and other lipopeptides including iturin A, fengycin, and surfactin [68-70]. In addition, it has also been observed that xanthobaccin A secreted by Stenotrophomonas sp. strain SB-K88 [71], zwittermicin A [72,73], and kanosamine [74] produced by Bacillus cereus UW85, prodigiosin produced by Serratia spp. $[75,76]$, and volatile organic compounds like ketones and pyrazine released by Bacillus spp. [69], can all be antagonistic against pathogenic fungi in vitro.

Howell and Stipanovic (1980) found that antibiotic pyoluteorin synthesized by P. fluorescens Pf-5 was inhibitory to Pythium ultimum, but not to Rhizoctonia solani, on cotton [55]. Nielsen and Sørensen (2003) showed that fluorescent Pseudomonas strains differ in their abilities to produce antifungal cyclic lipopeptides (CLPs) in the sugar beet rhizosphere, e.g., P. fluorescens DR54 accumulated a high viscosinamide level, while $P$. fluorescens strains 96.578 and DSS73 exhibited a significant accumulation of tensin or amphisin [77]. Moreover, certain P. fluorescens strain groups (e.g., biotypes I, V, or VI) are affiliated with the production of specific CLPs against root-pathogenic fungi [78]. Antibiotic synthesis by PGPR closely relates to the cell metabolic status, which, in turn, is influenced by biotic and abiotic stimuli [79], including host plant growth, type of substrate and supply, temperature, oxygen availability, and $\mathrm{pH}$. It is noteworthy that many strains can produce suites of secondary antibiotics, and that conditions favorable for production of one antibiotic compound are likely unfavorable to produce another [80]. This being the case, importantly, the assemblages of diverse PGPR strains offer a higher degree of flexibility and biocontrol effectiveness for the antagonists, particularly when PGPR are confronted with heterogeneous or changeable conditions.

\subsection{Enzyme Lysis}

A wide variety of PGPR showing hyperparasitic activity attack pathogens through secretion of cell wall hydrolases, such as chitinases, glucanases, cellulases, and proteases [81]. For example, Serratia plymuthica secreting chitinase hampers germination and germ tube elongation of the pathogenic fungus Botrytis cinerea [82]. The ability to produce $\beta-1,3-$ glucanase is critical for Pseudomonas cepacia to deconstruct cell walls of Rhizoctonia solani, Pythium ultimum, and Sclerotium rolfsii [83]. Singh et al. (1999) showed that Paenibacillus sp. 300 and Streptomyces sp. 385 both synthesize chitinase and $\beta$-1,3-glucanase to lyse cell walls of the pathogenic fungus Fusarium oxysporum f. sp. cucumerinum [84]. Bacillus sp. BPR7 possesses chitinase and $\beta$-1,4-glucanase activities that inhibit the growth of fungal pathogens, such as F. oxysporum, F. solani, and R. solani in vitro [85]. Bacillus thuringiensis UM96 produces chitinase to inhibit mycelial growth of B. cinerea [86], the cell walls of which could also be degraded by B. atrophaeus JZB120050, which produces chitinase, glucanase, and protease [87]. Bacillus subtilis RH5 secretes chitinase, protease, cellulase, and xylanase that act against $R$. solani [88]. Further, Paenibacillus ehimensis KWN38 showed high activities of chitinase, cellulase, glucanase, and protease against $R$. solani AG-1, F. oxysporum f. sp. lycopersici, and Phytophthora capsici [89].

Chitinolytic activity seems non-essential for Serratia plymuthica IC14 acting against $B$. cinerea and Sclerotinia sclerotiorum; rather, it involves the synthesis of other enzymes, such as proteases [90]. Similarly, of the hydrolytic enzymes cellulase, protease, chitinase, and pectinase produced by Paenibacillus sp. B2, only protease was responsible for inhibition of the mycelial growth of Phytophthora parasitica [91]. Importantly, it is highly likely that a wider array of enzymes produced by different species of PGPR in mixture will have greater advantage of suppressing multiple pathogens present in the host rhizosphere due to complementary action of their lytic enzymes.

\subsection{Induction of Systemic Resistance}

Induced systemic resistance (ISR) is a state of active resistance due to an inducing agent after pathogen infection. ISR can be induced by beneficial rhizobacteria, whereas the pathogen-induced resistance is called systemic acquired resistance (SAR) [92] (Figure 1a). The induced resistance confers non-specific protection against a broad spectrum of attack- 
ers, including fungi, bacteria, virus, insects and nematodes [12]. SAR involves salicylic acid (SA) and changes in gene expression related to pathogenesis-related proteins (PR proteins). Most PGPR employ an SA-independent pathway to activate ISR, a pathway involving jasmonate and ethylene signaling [93]. These hormones are implicated in activating certain sets of defense-related gene expression in plants and/or spreading the defense mechanisms into distal plant tissues, leading to host morphological and metabolic responses, such as cell wall strengthening, accumulation of PR proteins or defense-related enzymes (e.g., chitinase, glucanase, peroxidase, polyphenol oxidase, phenylalanine ammonia lyase, chalcone synthase, lipoxygenase, etc.), and syntheses of phenolic compounds and phytoalexins $[94,95]$.

Several bacterial traits have previously been identified as elicitors of ISR, including flagella, cell envelope component lipopolydaccharides (LPS), and secreted metabolites such as siderophores [94,96], salicylic acid [97,98], and antibiotics like 2,4-diacetylphloroglucinol (DAPG) [99] and pyocyanin [100]. The accumulated evidence indicates that many other traits of PGPR are also operative in eliciting ISR. For example, volatile organic compounds 2R,3R-butanediol emitted by Bacillus subtilis GB03, branched-chain alcohols by B. amyloliquefaciens IN937a [101,102], dimethyl disulfide (DMDS) by B. cereus C1L [103], and quorum-sensing molecules including $N$-acylhomoserine lactones (AHLs) produced by Serratia liquefaciens MG1, Pseudomonas putida IsoF [104], and Serratia plymuthica HRO-C48 [105]. Some of the ISR elicitors function redundantly, e.g., the flagella, LPS-containing cell walls, and siderophore pseudobactin of P. putida WCS358 all can induce systemic resistance in Arabidopsis thaliana when exogenously applied to the roots [106]. However, P. putida WCS358 mutants, defective in flagellation, in immunizing O-antigenic side chain of the lipopolysaccharides or in pseudobactin synthesis, were still effective in triggering ISR [106].

Strains of PGPR vary in effectiveness in inducing systemic resistance [107], and the induction of systemic resistance is reliant on strain-specific traits [108]. Importantly, Jetiyanon and Kloepper (2002) showed that mixtures of compatible dual PGPR strains eliciting induced systemic resistance to different pathogens in several plant hosts provided greater suppression of diseases than the individual strains [109]. Similarly, a dual bacterial consortium containing P. putida CRN-09 and B. subtilis CRN-16 conferred significantly greater expression of ISR to Macrophomina phaseolina in mung bean as compared with the application of a single strain, by enhancing activities of phenylalanine ammonia lyase, polyphenol oxidase, peroxidase, $\beta$-1,3-glucanase, and chitinase [110]. Dutta et al. (2008) using a split root experiment, found that the combination of RRLJ04 or BS03 with the rhizobial strain RH2 was better in inducing systemic resistance than their individual treatments [111]. Further, Berendsen et al. (2018) demonstrated that while a Xanthomonas sp., a Stenotrophomonas sp., and a Microbacterium sp. did not affect the plant separately, the triple bacterial consortium induced systemic resistance against Hyaloperonospora arabidopsidis and promoted plant growth [112]. These studies highlight the increased expression of and benefits from varied traits using PGPR mixtures. It is clear that the use of PGPR mixtures covers greater trait variation and complementarity and hence increases the likelihood of success, and at least reliability, in activating host systemic resistance against pathogen infection and provide broad-spectrum protection against different pathogens.

\subsection{Signal Interference}

Many phytopathogenic bacteria only evoke pathogenicity or virulence factors at a high bacterial population density by detecting the accumulated levels of quorum-sensing (QS) molecules (also known as autoinducers) such as AHLs [11]. Signal interference is a mechanism of biocontrol based on the interference with QS through enzymatic degradation of the autoinducers. For example, lactonases of Bacillus thuringiensis hydrolyze the AHL lactone ring [113], and acylases of Ralstonia sp. cleave the AHL amide [114]. Growing evidence highlights additional AHL-degrading enzymes with different specificity and kinetics in a great variety of PGPR species/strains, among which are Bacillus spp. [115-117], Pseudomonas spp. [118-120], Comamonas sp. D1 [121,122], Arthrobacter sp. 
IBN110 [117], Actinobacter sp. C1010 [123], Rhodococcus erythropolis W2 [121,124], Streptomyces sp. M664 [125], Rhodococcus sp. LS31 and PI33 [126], Ochrobactrum sp. T63 [127], Mesorhizobium sp. S5 [116], and Microbacterium testaceum StLB037 [128,129]. Jayanna and Umesha (2017) reported that the ability of P. aeruginosa 2apa to degrade AHL by acylase also inhibits the biofilm formation of Ralstonia solanacearum in vivo [120]. Biocontrol is likely fostered when biofilm formation is impaired or absent. In Vitro, Rhodococcus erythropolis and Bacillus simplex reduced the pathogenicity of Agrobacterium tumefaciens [121] and Erwinia amylovora [130] via quenching AHL-quorum sensing. Studies are rare that examine the effects of PGPR assemblages of varying richness with regard to this mechanism. However, the wide diversity of AHL-degrading PGPR used in assemblages may provide greater opportunities for effective biocontrol towards AHL-utilizing phytopathogens.

\section{PGPR Mixtures in Disease Suppression}

In natural habitats, PGPR live in multi-species assemblages in soil or plant rhizosphere [20,131]. Given the community-based lifestyle of PGPR, it is advocated to use mixed PGPR of diverse species to enhance the efficiency and reliability of disease control in different agricultural fields, with an assumption that the mixture will confer synergistic control of the tested pathogens (Table 1). Pseudomonas fluorescens F113 and Stenotrophomonas maltophilia W81 prevent damping-off of sugar beet through the production of DAPG and extracellular proteolytic activity, respectively, and in a field experiment only co-inoculation of W81 and F113 prevented the disease [132]. Both P. fluorescens sp. M23 and Bacillus sp. MRF produce antifungal antibiotics and siderophores, and are efficient in rhizosphere colonization, such that when co-inoculated on maize plants there was significantly decreased infection of Fusarium spp. in comparison with untreated control plants and with a single bacterial agent treatment [33]. Similarly, the mixture of Bacillus amyloliquefaciens IN937a and B. pumilus IN937b elicited systemic resistance, leading to more consistent broad-spectrum pathogen control in various crops under field conditions in comparison with an individual strain [133], and this Bacillus strain mixture had 25-30\% greater superoxide dismutase and peroxidase activities than the non-bacterized control [134]. In the same way, a combination of $P$. putida strains WCS358 and RE8 reduced Fusarium wilt incidence in radish by up to $50 \%$ as compared to the $30 \%$ reduction from the individual strain [135]. In this case, by applying the strain mixture, two different disease-suppressive mechanisms (i.e., competing for iron through pseudobactin production for WCS358, and inducing systemic resistance for RE8) acted together to enhance disease suppression. It was also possible that these two strains colonized different niches and so limiting competition between them for iron [135]. Burkholderia spp. RHT8 and RTH12 both showed the production of siderophores as well as chitinase and $\beta$-1,3-glucanase; and the co-inoculation treatment suppressed Fusarium oxysporum leading to increased growth and yield of fenugreek in both in vitro and in field conditions, as compared to single inoculation and non-inoculated control [136]. In these examples, enhanced disease suppression in a bacterial mixture not only likely involves different disease-suppressive mechanisms but may also result from interactions between two or more introduced PGPR strains positively affecting (anti-pathogen) activity, root colonization, and growth of the bacterial strains. 
Table 1. PGPR mixtures effective against different plant pathogens along with their mechanisms of action with example case studies.

\begin{tabular}{|c|c|c|c|c|c|}
\hline Mechanisms of Action & Host Plants & Diseases/Pathogens & Effective PGPR Inoculation & Trial Conditions & References \\
\hline \multicolumn{6}{|c|}{ Competitive rhizosphere colonization + Antibiosis } \\
\hline $\begin{array}{l}\text { Production of siderophores and antibiotics } \\
\text { along with successful rhizotic zone } \\
\text { colonization } \\
\text { by these strains }\end{array}$ & $\begin{array}{l}\text { Maize } \\
\text { (Zea mays) }\end{array}$ & $\begin{array}{l}\text { Root diseases } \\
\text { (Fusarium } \\
\text { moniliforme, F. graminearum and } \\
\text { Macrophomina phaseolina) }\end{array}$ & $\begin{array}{l}\text { Bacillus sp. } \\
\text { MR-11(2) + Bacillus sp. MRF; } \\
\text { Pseudomonas fluorescens sp. M23 + } \\
\text { Bacillus sp. MRF }\end{array}$ & Pot & $\begin{array}{l}\text { Pal et al., } 2001 \\
\text { [33] }\end{array}$ \\
\hline Antibiosis + Enzyme lysis & & & & & \\
\hline $\begin{array}{l}\text { Production of DAPG by } P \text {. fluorescens F113; } \\
\text { production of extracellular proteolytic } \\
\text { enzymes by S. maltophilia W81 }\end{array}$ & $\begin{array}{l}\text { Sugar beet } \\
\text { (Beta vulgaris) }\end{array}$ & $\begin{array}{l}\text { Damping-off } \\
\text { (Pythium spp.) }\end{array}$ & $\begin{array}{l}\text { Pseudomonas fluorescens F113 + } \\
\text { Stenotrophomonas maltophilia W81 }\end{array}$ & $\begin{array}{l}\text { Pot and } \\
\text { field }\end{array}$ & $\begin{array}{l}\text { Dunne et al., } 1998 \\
\text { [132] }\end{array}$ \\
\hline \multicolumn{6}{|c|}{ Competitive rhizosphere colonization + Induction of systemic resistance } \\
\hline $\begin{array}{l}\text { Pseudobactin-mediated competition for } \\
\text { iron for P. putida WCS358; induction of } \\
\text { systemic resistance for RE8 }\end{array}$ & Radish (Raphanus sativus) & $\begin{array}{l}\text { Fusarium wilt (Fusarium } \\
\text { oxysporum f. sp. raphani) }\end{array}$ & $\begin{array}{l}\text { Pseudomonas putida WCS } 358 \\
+ \text { P. putida RE8 }\end{array}$ & Pot & $\begin{array}{l}\text { de Boer et al., } 2003 \\
\text { [135] }\end{array}$ \\
\hline \multicolumn{6}{|c|}{ Competitive rhizosphere colonization + Enzyme lysis } \\
\hline $\begin{array}{l}\text { Production of siderophore as } \\
\text { well as chitinase and } \beta-1,3 \text {-glucanase by } \\
\text { both strains }\end{array}$ & $\begin{array}{l}\text { Fenugreek (Trigonella } \\
\text { foenum-graecum) }\end{array}$ & $\begin{array}{l}\text { Fusarium wilt (Fusarium } \\
\text { oxysporum) }\end{array}$ & $\begin{array}{l}\text { Burkholderia sp. RHT8 + Burkholderia } \\
\text { sp. RTH12 }\end{array}$ & $\begin{array}{l}\text { In vitro } \\
\text { and field }\end{array}$ & $\begin{array}{l}\text { Kumar et al., } 2017 \\
{[136]}\end{array}$ \\
\hline \multicolumn{6}{|c|}{ Competitive rhizosphere colonization + Antibiosis + Enzyme lysis } \\
\hline $\begin{array}{l}\text { Siderophore production by } R \text {. } \\
\text { leguminosarum RPN5; production of } \\
\text { siderophore, HCN, chitinase, } \\
\beta-1,3 \text {-glucanase, } \beta-1,4 \text {-glucanase by Bacillus } \\
\text { sp. BPR7 and Pseudomonas sp. PPR } 8 \\
\text { Induction of systemic resistance }\end{array}$ & $\begin{array}{l}\text { Common bean (Phaseolus } \\
\text { vulgaris) }\end{array}$ & $\begin{array}{l}\text { Macrophomina phaseolina, Fusarium } \\
\text { oxysporum, F. solani, Rhizoctonia } \\
\text { solani, Colletotrichum sp. } \\
\text { and Sclerotinia sclerotiorum }\end{array}$ & $\begin{array}{l}\text { Rhizobium leguminosarum RPN5 + } \\
\text { Bacillus sp. BPR7 + Pseudomonas sp. } \\
\text { PPR8 }\end{array}$ & $\begin{array}{l}\text { Pot and } \\
\text { field }\end{array}$ & $\begin{array}{l}\text { Kumar et al., } 2016 \\
{[137]}\end{array}$ \\
\hline $\begin{array}{l}\text { Induced systemic resistance by individual } \\
\text { strains and their mixture }\end{array}$ & Mung bean (Vigna radiata) & $\begin{array}{l}\text { Root rot and } \\
\text { leaf blight (Macrophomina } \\
\text { phaseolina) }\end{array}$ & $\begin{array}{l}\text { Pseudomonas putida CRN-09+ Bacillus } \\
\text { subtilis CRN-16 }\end{array}$ & Pot & $\begin{array}{l}\text { Sharma et al., } 2018 \\
\text { [110] }\end{array}$ \\
\hline $\begin{array}{l}\text { Induced systemic resistance by } B \text {. cereus } \\
\text { BS03 or P. aeruginosa RRLJ04, and the } \\
\text { respective strain mixture }\end{array}$ & $\begin{array}{l}\text { Pigeon pea (Cajanus } \\
\text { cajan) }\end{array}$ & $\begin{array}{l}\text { Fusarial wilt } \\
\text { (Fusarium udum) }\end{array}$ & $\begin{array}{l}\text { Bacillus cereus BS03 + Rhizobium sp. } \\
\text { RH2; } \\
\text { Pseudomonas aeruginosa RRLJ04 + } \\
\text { Rhizobium sp. RH2 }\end{array}$ & Pot & $\begin{array}{l}\text { Dutta et al., } 2008 \\
{[111]}\end{array}$ \\
\hline $\begin{array}{l}\text { Induced systemic resistance by a mixture of } \\
\text { individual strains }\end{array}$ & Arabidopsis thaliana & $\begin{array}{l}\text { Downy mildew (Hyaloperonospora } \\
\text { arabidopsidis) }\end{array}$ & $\begin{array}{l}\text { Xanthomonas sp. }+ \text { Stenotrophomonas } \\
\mathrm{sp} .+ \text { Microbacterium } \mathrm{sp} \text {. }\end{array}$ & Pot & $\begin{array}{l}\text { Berendsen et al., } 2018 \\
\text { [112] }\end{array}$ \\
\hline $\begin{array}{l}\text { Induced systemic resistance } \\
\text { by individual strains or their mixture }\end{array}$ & $\begin{array}{l}\text { Tomato (Lycopersicon esculentum), } \\
\text { pepper (Capsicum annuum) and } \\
\text { cucumber (Cucumis sativus) }\end{array}$ & $\begin{array}{l}\text { Southern blight (Sclerotium rolfsii) } \\
\text { of tomato, } \\
\text { anthracnose (Colletotrichum } \\
\text { gloeosporioides) of pepper, and } \\
\text { mosaic disease (Cucumber mosaic } \\
\text { virus) of cucumber }\end{array}$ & $\begin{array}{l}\text { Bacillus amyloliquefaciens IN937a }+B \text {. } \\
\text { pumilus IN937b }\end{array}$ & Field & $\begin{array}{l}\text { Jetiyanon et al., } 2003 \\
\text { [133] }\end{array}$ \\
\hline
\end{tabular}


Table 1. Cont.

\begin{tabular}{|c|c|c|c|c|c|}
\hline Mechanisms of Action & Host Plants & Diseases/Pathogens & Effective PGPR Inoculation & Trial Conditions & References \\
\hline $\begin{array}{l}\text { Increased superoxide dismutase (SOD) and } \\
\text { peroxidase (PO) activities due to systemic } \\
\text { resistance induced by the Bacillus strain } \\
\text { mixture }\end{array}$ & Tomato and pepper & $\begin{array}{l}\text { Sclerotium rolfsii and Ralstonia } \\
\text { solanacearum } \\
\text { in tomato; S. rolfsii } \\
\text { and } \\
\text { Colletotrichum } \\
\text { gloeosporioides in pepper }\end{array}$ & $\begin{array}{l}\text { Bacillus amyloliquefaciens IN937a }+B \text {. } \\
\text { pumilus IN937b }\end{array}$ & Pot & $\begin{array}{l}\text { Jetiyanon } 2007 \\
\text { [134] }\end{array}$ \\
\hline $\begin{array}{l}\text { Induced systemic resistance by individual } \\
\text { strains and their mixture }\end{array}$ & $\begin{array}{l}\text { Rice } \\
\text { (Oryza } \\
\text { sativa) }\end{array}$ & $\begin{array}{l}\text { Rice blast } \\
\text { (Pyricularia } \\
\text { oryzae) }\end{array}$ & $\begin{array}{l}\text { Pseudomonas fluorescens Aur6 + } \\
\text { Chryseobacterium balustinum Aur9 }\end{array}$ & Field & $\begin{array}{l}\text { Lucas et al., } 2009 \\
{[138]}\end{array}$ \\
\hline $\begin{array}{l}\text { An increase in the enzyme activity } \\
\text { including chitinase, } \beta \text {-1,3-glucanase, and } \\
\text { polyphenol oxidase induced by both strains } \\
\text { Signal interference }\end{array}$ & $\begin{array}{l}\text { Ginger } \\
\text { (Zingiber officinale) }\end{array}$ & $\begin{array}{l}\text { Rhizome rot } \\
\text { (Fusarium solani } \\
\text { and F. oxysporum) }\end{array}$ & $\begin{array}{l}\text { Bacillus subtilis } \\
+ \text { Burkholderia cepacia }\end{array}$ & $\begin{array}{l}\text { Pot and } \\
\text { field }\end{array}$ & $\begin{array}{l}\text { Shanmugam et al., } 2013 \\
\text { [139] }\end{array}$ \\
\hline $\begin{array}{l}\text { Degrading AHL by acylase and inhibiting } \\
\text { biofilm formation }\end{array}$ & & $\begin{array}{l}\text { Ralstonia } \\
\text { Solanacearum } \\
\text { (single inoculation) }\end{array}$ & Pseudomonas aeruginosa 2apa & In vivo & $\begin{array}{l}\text { Jayanna and Umesha, } \\
2017 \\
{[120]}\end{array}$ \\
\hline
\end{tabular}




\section{Limitations to PGPR Mixture}

There is also evidence that certain PGPR mixtures do not exhibit synergistic or comparable effects on disease control and plant growth, with respect to their single strains [140-142]. For example, a mixture of lytic non-fluorescent and siderophore-producing fluorescent bacteria did not increase suppressiveness to Fusarium wilt of cucumber [37]. Pseudomonas chlororaphis PCL1391 and P. fluorescens WCS365 suppress plant diseases mainly by the production of antibiotic phenazine [53] and by induction of host systemic resistance [61], respectively. However, although the combination of the two bacteria promoted plant growth, there was no significant difference in control of bean anthracnose from the mixtures as compared to only treatment with strain PCL1391 [143].

The antagonism between biocontrol bacterial agents used in mixtures or between a biocontrol agent and the indigenous microflora can undermine the performance of bacterial agents in the rhizosphere. This is particularly so when two or more populations of microbes colonize the same ecological niche and have similar nutritional requirements [144] such that competition for niches and nutrients (niche exclusion) will be inevitable. For example, effective iron competition by endemic Pseudomonas spp. led to the ineffective control from Trichoderma hamatum for Pythium seed rot of pea [145]. Similarly, P. putida WCS358 decreased rhizosphere colonization of radish by P. fluorescens WCS374 and eight indigenous Pseudomonas strains, and siderophore-mediated competition for iron was the main determinant in these negative interactions [146]. Additionally, competition for limited carbon between P. fluorescens Ag1 and Alcaligenes eutrophus JMP134 decreased the population size of JMP134 in the rhizosphere of barley [147]. Secondary metabolites secreted by one organism impeding the growth of or disease control from the other organism is another antagonism that can occur between two populations of biocontrol agents [148]. For example, Molina et al. (2003) illustrated that Pseudomonas chlororaphis PCL1391 suppresses Fusarium oxysporum-inducing vascular wilt of tomato by production of phenazine, which is controlled by AHL-mediated QS. When co-inoculated with AHL-degrader P. fluorescens P3/pME6863, the antifungal activity and protection of this biocontrol agent against vascular wilt was markedly attenuated [149]. These negative interactions can restrict the activity of, and/or the colonization by, inoculated PGPR strains, particularly where the rhizosphere population density of one or all strains fail to reach the threshold level needed for disease suppression to occur $[17,19]$. In contrast to the above examples, Felici et al. (2008) found that a lack of synergistic impacts of dual bacterial inoculation (Bacillus subtilis 101 and Azospirillum brasilense Sp24) was not related to reduced persistence of one or both bacteria in the rhizosphere, but rather due to the implication of independent signaling pathways associated with different modes of action in the two bacterial species [141]. Hence, compatibility of strains of PGPR mixtures is an essential prerequisite for better biocontrol efficacy and stability of biocontrol agents. Further, the interactions (e.g., synergistic, antagonistic, and neutral) between members of synthetic microbial communities shape their functioning and evolution in either constant or in fluctuating environments [150], but historical studies have rarely assessed the fate of bacteria in soil when introduced as a mixture, nor the effect of bacterial mixtures on the microbial communities including macro-organisms, present in the rhizosphere. This critical area of research deserves far more attention in order to better utilize PGPR mixtures in improving their efficacies.

\section{Critical Approaches towards Developing Successful PGPR Mixtures}

Various rhizosphere bacteria are potential biological pesticides capable of protecting plants against diseases and improving plant fitness and yield. To increase and maintain the level of biological control, multiple strain mixtures of PGPR have been employed successfully in many crops, especially when individual strains are unable to provide adequate suppression of pathogens. A range of biocontrol mechanisms, such as competitive rhizosphere colonization, secretion of antibiotics and enzymes, signal interference, and induced systemic resistance, may operate in mixed PGPR populations and strengthen the ability of the combined partners in an additive or synergistic manner (Figure 1), which is 
possibly correlated to the potency exerted by biodiversity [151,152]. Although the relative significance of each mechanism is unknown and might vary with circumstances, it is evident that multiple mechanisms function in biocontrol systems under field conditions. Clearly, PGPR mixtures have the advantage of combining their diverse traits, in particular the traits that are hard to find in a single bacterium. Moreover, as PGPR mixtures more closely mimic the microbial communities present in the rhizosphere, application of such mixtures should enable better preparation and tolerance when faced with the challenges of varied biotic or abiotic conditions that may otherwise reduce variability in biocontrol efficacies [153]. This increased level of stability in biocontrol is also often observed in mixtures of plant cultivars [154], of fungicides [155], and sometimes even of arbuscular mycorrhizal fungi [156].

Since external biotic and abiotic factors shape the microbial communities in soil [157], the performance of different mechanisms of biocontrol by PGPR is likely dissimilarly affected by them. Dominant factors comprise challenges, such as inadequate rhizosphere colonization, limited tolerance to environmental/climate changes, and fluctuating production or activity of antimicrobial metabolites (antibiotics, enzymes, etc.) $[8,158,159]$, which are often overlooked when PGPR mixtures are developed artificially to treat plants. While artificially combined PGPR mixtures may bring in increased, unchanged, or decreased disease-suppressive effects [160], there remain significant prospects for increased disease control from PGPR mixtures if the underlying interactions are better understood. Several determinant factors presumably account for the success of some PGPR mixtures in disease control. First, individual PGPR strains/species have differing substrate utilization profiles with niche preferences or differentiation in the root zone [161], where higher levels of coexistence or compatibility should be expected, provided that PGPR strains differ in their ecological requirements for survival, colonization, and activity. Additionally, diverse bacterial populations occupy different niches in the rhizosphere and/or generate specialization in the same niches [6], and hence restrict competition from competing strains/species of PGPR and strengthen cooperation among them. Second, individual PGPR strains/species exert complementary disease-suppressive mechanisms (traits) [132,135], such that when one mechanism is ineffective under a particular set of conditions, the others can compensate for the former absence. Third, the effects of similar or different mechanisms of action employed by different strains may augment quantitatively in a beneficial way $[44,112]$ (Figure 1b).

Recently, using metatranscriptomic analysis, Gómez-Godínez et al. (2019) revealed that Azospirillum nif genes were upregulated in the presence of other PGPR species, resulting in active nitrogen fixation by A. brasilense in maize roots [15]. Similarly, it was shown that the individual bacterial agents within PGPR communities differentially express their disease-suppressive traits [14,16], and accordingly induce the tuning of genes and metabolic pathways in host plants to achieve specific targets that benefit agriculture. Indeed, specific interactions between PGPR strains can influence the level of pathogen suppressiveness through combination of these strains [148,160], and the functioning of individual strains within a bacterial consortium can be used to predict the performance of the bacterial communities and associated phenotypes in the hosts [162]. To secure additive and more synergistic interacting outcomes, future investigations into the use of different strains/species of PGPR in combinations need to quantitatively determine the key biocontrol processes and their interactions, and the benefits conferred should be categorized and quantified (e.g., via functional analyses employing transcriptomics, proteomics, and metabolomics under contrasting conditions). For instance, it would be informative to determine how bacterial mixture-mediated metabolic and transcriptional regulations are positively associated with plant defense responses during biotic and/or abiotic challenges [163]. This represents the next logical step towards the development of compatible PGPR mixtures with improved biocontrol efficacy and stability for utilization in heterogeneous agricultural systems. 
Author Contributions: H.W. wrote the initial version of the manuscript and figure. H.W., R.L., M.P.Y., M.J.B., and Y.C. revised and improved the manuscript. All authors have read and agreed to the published version of the manuscript.

Funding: This research and the APC was funded by the National Natural Science Foundation of China, grant number 42077055 .

Conflicts of Interest: The authors declare no potential conflict of interest.

\section{References}

1. Hardoim, P.R.; van Overbeek, L.S.; Berg, G.; Pirttilä, A.M.; Compant, S.; Campisano, A.; Döring, M.; Sessitsch, A. The hidden world within plants: Ecological and evolutionary considerations for defining functioning of microbial endophytes. Microbiol. Mol. Biol. Rev. 2015, 79, 293-320. [CrossRef] [PubMed]

2. Bukhat, S.; Imran, A.; Javaid, S.; Shahid, M.; Majeed, A.; Naqqash, T. Communication of plants with microbial world: Exploring the regulatory networks for PGPR mediated defense signaling. Microbiol. Res. 2020, 238, 126486. [CrossRef]

3. Kumar, A.; Verma, J.P. Does plant-Microbe interaction confer stress tolerance in plants: A review? Microbiol. Res. 2018, 207, 41-52. [CrossRef] [PubMed]

4. Adedeji, A.A.; Häggblom, M.M.; Babalola, O.O. Sustainable agriculture in Africa: Plant growth-promoting rhizobacteria (PGPR) to the rescue. Sci. Afr. 2020, 9, e00492. [CrossRef]

5. Sarma, B.K.; Yadav, S.K.; Singh, S.; Singh, H.B. Microbial consortium-mediated plant defense against phytopathogens: Readdressing for enhancing efficacy. Soil Biol. Biochem. 2015, 87, 25-33. [CrossRef]

6. Besset-Manzoni, Y.; Rieusset, L.; Joly, P.; Comte, G.; Prigent-Combaret, C. Exploiting rhizosphere microbial cooperation for developing sustainable agriculture strategies. Environ. Sci. Pollut. Res. 2018, 25, 29953-29970. [CrossRef]

7. Tabassum, B.; Khan, A.; Tariq, M.; Ramzan, M.; Iqbal Khan, M.S.; Shahid, N.; Aaliya, K. Bottlenecks in commercialisation and future prospects of PGPR. Appl. Soil Ecol. 2017, 121, 102-117. [CrossRef]

8. Compant, S.; Duffy, B.; Nowak, J.; Clément, C.; Barka, E.A. Use of plant growth-promoting bacteria for biocontrol of plant diseases: Principles, mechanisms of action, and future prospects. Appl. Environ. Microbiol. 2005, 71, 4951-4959. [CrossRef]

9. Barea, J.M.; Pozo, M.J.; Azcón, R.; Azcón-Aguilar, C. Microbial co-operation in the rhizosphere. J. Exp. Bot. 2005, 56, 1761-1778. [CrossRef]

10. Lugtenberg, B.; Kamilova, F. Plant-growth-promoting rhizobacteria. Annu. Rev. Microbiol. 2009, 63, 541-556. [CrossRef]

11. Helman, Y.; Chernin, L. Silencing the mob: Disrupting quorum sensing as a means to fight plant disease. Mol. Plant Pathol. 2015, 16, 316-329. [CrossRef]

12. Beneduzi, A.; Ambrosini, A.; Passaglia, L.M.P. Plant growth-promoting rhizobacteria (PGPR): Their potential as antagonists and biocontrol agents. Genet. Mol. Biol. 2012, 35, 1044-1051. [CrossRef]

13. Ali, S.; Hameed, S.; Shahid, M.; Iqbal, M.; Lazarovits, G.; Imran, A. Functional characterization of potential PGPR exhibiting broad-spectrum antifungal activity. Microbiol. Res. 2020, 232, 126389. [CrossRef]

14. Kadyan, S.; Panghal, M.; Kumar, S.; Singh, K.; Yadav, J.P. Assessment of functional and genetic diversity of aerobic endospore forming Bacilli from rhizospheric soil of Phyllanthus amarus L. World J. Microbiol. Biotechnol. 2013, 29, 1597-1610. [CrossRef] [PubMed]

15. Gómez-Godínez, L.J.; Fernandez-Valverde, S.L.; Martinez Romero, J.C.; Martínez-Romero, E. Metatranscriptomics and nitrogen fixation from the rhizoplane of maize plantlets inoculated with a group of PGPRs. Syst. Appl. Microbiol. 2019, 42, 517-525. [CrossRef] [PubMed]

16. Rasool, A.; Imran Mir, M.; Zulfajri, M.; Hanafiah, M.M.; Azeem Unnisa, S.; Mahboob, M. Plant growth promoting and antifungal asset of indigenous rhizobacteria secluded from saffron (Crocus sativus L.) rhizosphere. Microb. Pathog. 2021, 150, 104734. [CrossRef] [PubMed]

17. Raaijmakers, J.M.; Bonsall, R.F.; Weller, D.M. Effect of population density of Pseudomonas fluorescens on production of 2,4diacetylphloroglucinol in the rhizosphere of wheat. Phytopathology 1999, 89, 470-475. [CrossRef] [PubMed]

18. Weller, D.M. Biological control of soilborne plant pathogens in the rhizosphere with bacteria. Annu. Rev. Phytopathol. 1988, 26, 379-407. [CrossRef]

19. Bloemberg, G.V.; Lugtenberg, B.J.J. Molecular basis of plant growth promotion and biocontrol by rhizobacteria. Curr. Opin. Plant Biol. 2001, 4, 343-350. [CrossRef]

20. Vacheron, J.; Desbrosses, G.; Bouffaud, M.L.; Touraine, B.; Moënne-Loccoz, Y.; Muller, D.; Legendre, L.; Wisniewski-Dyé, F.; Prigent-Combaret, C. Plant growth-promoting rhizobacteria and root system functioning. Front. Plant Sci. 2013, 4, 356. [CrossRef] [PubMed]

21. Olanrewaju, O.S.; Ayangbenro, A.S.; Glick, B.R.; Babalola, O.O. Plant health: Feedback effect of root exudates-rhizobiome interactions. Appl. Microbiol. Biotechnol. 2019, 103, 1155-1166. [CrossRef] [PubMed]

22. Bacilio-Jiménez, M.; Aguilar-Flores, S.; Ventura-Zapata, E.; Pérez-Campos, E.; Bouquelet, S.; Zenteno, E. Chemical characterization of root exudates from rice (Oryza sativa) and their effects on the chemotactic response of endophytic bacteria. Plant Soil 2003, 249, 271-277. [CrossRef] 
23. Reinhold, B.; Hurek, T.; Fendrik, I. Strain-specific chemotaxis of Azospirillum spp. J. Bacteriol. 1985, 162, 190-195. [CrossRef] [PubMed]

24. de Souza, R.S.C.; Armanhi, J.S.L.; Damasceno, N.B.; Imperial, J.; Arruda, P. Genome sequences of a plant beneficial synthetic bacterial community reveal genetic features for successful plant colonization. Front. Microbiol. 2019, 10, 1779. [CrossRef]

25. Bais, H.P.; Park, S.-W.; Weir, T.L.; Callaway, R.M.; Vivanco, J.M. How plants communicate using the underground information superhighway. Trends Plant Sci. 2004, 9, 26-32. [CrossRef] [PubMed]

26. Philippot, L.; Raaijmakers, J.M.; Lemanceau, P.; van der Putten, W.H. Going back to the roots: The microbial ecology of the rhizosphere. Nat. Rev. Microbiol. 2013, 11, 789-799. [CrossRef] [PubMed]

27. Elad, Y.; Chet, I. Possible role of competition for nutrients in biocontrol of Pythium damping-off by bacteria. Phytopathology 1987, 77, 190-195. [CrossRef]

28. Mohamed, S.; Caunter, I.G. Isolation and characterization of a Pseudomonas fluorescens strain suppressive to Bipolaris maydis. J. Phytopathol. 1995, 143, 111-114. [CrossRef]

29. Scavino, A.F.; Pedraza, R.O. The role of siderophores in plant growth-promoting bacteria. In Bacteria in Agrobiology: Crop Productivity; Springer: Berlin/Heidelberg, Germany, 2013; pp. 265-285.

30. Haas, D.; Défago, G. Biological control of soil-borne pathogens by fluorescent pseudomonads. Nat. Rev. Microbiol. 2005, 3, 307-319. [CrossRef]

31. Ghosh, S.K.; Bera, T.; Chakrabarty, A.M. Microbial siderophore-A boon to agricultural sciences. Biol. Control 2020, $144,104214$. [CrossRef]

32. Scher, F.M.; Baker, R. Effect of Pseudomonas putida and a synthetic iron chelator on induction of soil suppressiveness to Fusarium wilt pathogens. Phytopathology 1982, 72, 1567-1573. [CrossRef]

33. Pal, K.K.; Tilak, K.V.B.R.; Saxcna, A.K.; Dey, R.; Singh, C.S. Suppression of maize root diseases caused by Macrophomina phaseolina, Fusarium moniliforme and Fusarium graminearum by plant growth promoting rhizobacteria. Microbiol. Res. 2001, 156, 209-223. [CrossRef]

34. Paulitz, T.C.; Loper, J.E. Lack of a role for fluorescent siderophore production in the biological control of Pythium damping-off of cucumber by a strain of Pseudomonas putida. Phytopathology 1991, 81, 930-935. [CrossRef]

35. Loper, J.E. Role of fluorescent siderophore production in biological control of Pythium ultimum by a Pseudomonas fluorescens strain. Phytopathology 1988, 78, 166-172. [CrossRef]

36. Trapet, P.; Avoscan, L.; Klinguer, A.; Pateyron, S.; Citerne, S.; Chervin, C.; Mazurier, S.; Lemanceau, P.; Wendehenne, D.; Besson-Bard, A. The Pseudomonas fluorescens siderophore pyoverdine weakens Arabidopsis thaliana defense in favor of growth in iron-deficient conditions. Plant Physiol. 2016, 171, 675-693. [CrossRef]

37. Sneh, B.; Dupler, M.; Elad, Y.; Baker, R. Chlamydospore germination of Fusarium oxysporum f. sp. cucumerinum as affected by fluorescent and lytic bacteria from a fusarium-suppressive soil. Phytopathology 1984, 74, 1115-1124. [CrossRef]

38. Buyer, J.S.; Leong, J. Iron transport-mediated antagonism between plant growth-promoting and plant-deleterious Pseudomonas strains. J. Biol. Chem. 1986, 261, 791-794. [CrossRef]

39. Loper, J.E.; Henkels, M.D. Utilization of heterologous siderophores enhances levels of iron available to Pseudomonas putida in the rhizosphere. Appl. Environ. Microbiol. 1999, 65, 5357-5363. [CrossRef] [PubMed]

40. Barahona, E.; Navazo, A.; Martínez-Granero, F.; Zea-Bonilla, T.; Pérez-Jiménez, R.M.; Martín, M.; Rivilla, R. Pseudomonas fluorescens F113 mutant with enhanced competitive colonization ability and improved biocontrol activity against fungal root pathogens. Appl. Environ. Microbiol. 2011, 77, 5412-5419. [CrossRef]

41. Chin-A-Woeng, T.F.C.; Bloemberg, G.V.; Mulders, I.H.; Dekkers, L.C.; Lugtenberg, B.J. Root colonization by phenazine-1carboxamide-producing bacterium Pseudomonas chlororaphis PCL1391 is essential for biocontrol of tomato foot and root rot. Mol. Plant Microbe Interact. 2000, 13, 1340-1345. [CrossRef]

42. Meneses, C.H.; Rouws, L.F.; Simoes-Araujo, J.L.; Vidal, M.S.; Baldani, J.I. Exopolysaccharide production is required for biofilm formation and plant colonization by the nitrogen-fixing endophyte Gluconacetobacter diazotrophicus. Mol. Plant Microbe Interact. 2011, 24, 1448-1458. [CrossRef] [PubMed]

43. Al-Ali, A.; Deravel, J.; Krier, F.; Béchet, M.; Ongena, M.; Jacques, P. Biofilm formation is determinant in tomato rhizosphere colonization by Bacillus velezensis FZB42. Environ. Sci. Pollut. Res. 2018, 25, 29910-29920. [CrossRef]

44. Guo, Q.; Shi, M.; Chen, L.; Zhou, J.; Zhang, L.; Li, Y.; Xue, Q.; Lai, H. The biocontrol agent Streptomyces pactum increases Pseudomonas koreensis populations in the rhizosphere by enhancing chemotaxis and biofilm formation. Soil Biol. Biochem. 2020, 144, 107755. [CrossRef]

45. Singh, R.; Sachan, N.S. Review on biological control of soil borne fungi in vegetable crops. HortFlora Res. Spectr. 2013, 2, 72-76.

46. Duffy, B.; Schouten, A.; Raaijmakers, J.M. Pathogen self-defense: Mechanisms to counteract microbial antagonism. Annu. Rev. Phytopathol. 2003, 41, 501-538. [CrossRef] [PubMed]

47. Maksimov, I.V.; Abizgil'dina, R.R.; Pusenkova, L.I. Plant growth promoting microorganisms as alternative to chemical protection from pathogens. Prikl. Biokhim. Mikrobiol. 2011, 47, 373-385. [PubMed]

48. Keel, C.; Schnider, U.; Maurhofer, M.; Voisard, C.; Laville, J.; Burger, U.; Wirthner, P.; Haas, D.; Défago, G. Suppression of root diseases by Pseudomonas fluorescens CHA0: Importance of the bacterial secondary metabolite 2,4-diacetylphloroglucinol. Mol. Plant Microbe Interact. 1992, 5, 4-13. [CrossRef] 
49. Keel, C.; Wirthner, P.; Oberhänsli, T.; Voisard, C.; Burger, U.; Haas, D.; Défago, G. Pseudomonads as antagonists of plant pathogens in the rhizosphere: Role of the antibiotic 2,4-diacetylphloroglucinol in the suppression of black root rot of tobacco. Symbiosis 1990, 9, 327-341.

50. de Souza, J.T.; Arnould, C.; Deulvot, C.; Lemanceau, P.; Gianinazzi-Pearson, V.; Raaijmakers, J.M. Effect of 2,4-diacetylphloroglucinol on pythium: Cellular responses and variation in sensitivity among propagules and species. Phytopathology 2003, 93, 966-975. [CrossRef]

51. Rai, R.; Srinivasamurthy, R.; Dash, P.K.; Gupta, P. Isolation characterization and evaluation of the biocontrol potential of Pseudomonas protegens RS-9 against Ralstonia solanacearum in tomato. Indian J. Exp. Biol. 2017, 55, 595-603.

52. Thomashow, L.S.; Weller, D.M.; Bonsall, R.F.; Pierson, L.S. Production of the antibiotic phenazine-1-carboxylic acid by fluorescent pseudomonas species in the rhizosphere of wheat. Appl. Environ. Microbiol. 1990, 56, 908-912. [CrossRef]

53. Chin-A-Woeng, T.F.C.; Bloemberg, G.V.; van der Bij, A.J.; van der Drift, K.M.G.M.; Schripsema, J.; Kroon, B.; Scheffer, R.J.; Keel, C.; Bakker, P.A.H.M.; Tichy, H.; et al. Biocontrol by phenazine1-carboxamide-producing Pseudomonas chlororaphis PCL1391 of tomato root rot caused by Fusarium oxysporum f. sp. radicis-lycopersici. Mol. Plant Microbe Interact. 1998, 11, 1069-1077. [CrossRef]

54. Mazurier, S.; Corberand, T.; Lemanceau, P.; Raaijmakers, J.M. Phenazine antibiotics produced by fluorescent pseudomonads contribute to natural soil suppressiveness to Fusarium wilt. ISME J. 2009, 3, 977-991. [CrossRef]

55. Howell, C.R.; Stipanovic, R.D. Suppression of Pythium ultimum-induced damping-off of cotton seedlings by Pseudomonas fluorescens and its antibiotic, pyoluteorin. Phytopathology 1980, 70, 712-715. [CrossRef]

56. Hassan, M.N.; Afghan, S.; Hafeez, F.Y. Biological control of red rot in sugarcane by native pyoluteorin-producing Pseudomonas putida strain NH-50 under field conditions and its potential modes of action. Pest. Manag. Sci. 2011, 67, 1147-1154. [CrossRef] [PubMed]

57. Ramette, A.; Frapolli, M.; Fischer-Le Saux, M.; Gruffaz, C.; Meyer, J.M.; Défago, G.; Sutra, L.; Moënne-Loccoz, Y. Pseudomonas protegens sp. nov., widespread plant-protecting bacteria producing the biocontrol compounds 2,4-diacetylphloroglucinol and pyoluteorin. Syst. Appl. Microbiol. 2011, 34, 180-188. [CrossRef]

58. Hill, D.S.; Stein, J.I.; Torkewitz, N.R.; Morse, A.M.; Howell, C.R.; Pachlatko, J.P.; Becker, J.O.; Ligon, J.M. Cloning of genes involved in the synthesis of pyrrolnitrin from Pseudomonas fluorescens and role of pyrrolnitrin synthesis in biological control of plant disease. Appl. Environ. Microbiol. 1994, 60, 78-85. [CrossRef] [PubMed]

59. Huang, R.; Feng, Z.; Chi, X.; Sun, X.; Lu, Y.; Zhang, B.; Lu, R.; Luo, W.; Wang, Y.; Miao, J.; et al. Pyrrolnitrin is more essential than phenazines for Pseudomonas chlororaphis G05 in its suppression of Fusarium graminearum. Microbiol. Res. 2018, $215,55-64$. [CrossRef]

60. Upadhyay, A.; Srivastava, S. Phenazine-1-carboxylic acid is a more important contributor to biocontrol Fusarium oxysporum than pyrrolnitrin in Pseudomonas fluorescens strain Psd. Microbiol. Res. 2011, 166, 323-335. [CrossRef]

61. Kamilova, F.; Validov, S.; Azarova, T.; Mulders, I.; Lugtenberg, B. Enrichment for enhanced competitive plant root tip colonizers selects for a new class of biocontrol bacteria. Environ. Microbiol. 2005, 7, 1809-1817. [CrossRef]

62. Lanteigne, C.; Gadkar, V.J.; Wallon, T.; Novinscak, A.; Filion, M. Production of DAPG and HCN by Pseudomonas sp. LBUM300 contributes to the biological control of bacterial canker of tomato. Phytopathology 2012, 102, 967-973. [CrossRef]

63. Moyne, A.L.; Shelby, R.; Cleveland, T.E.; Tuzun, S. Bacillomycin D: An iturin with antifungal activity against Aspergillus flavus. J. Appl. Microbiol. 2001, 90, 622-629. [CrossRef]

64. Xu, Z.; Shao, J.; Li, B.; Yan, X.; Shen, Q.; Zhang, R. Contribution of bacillomycin D in Bacillus amyloliquefaciens SQR9 to antifungal activity and biofilm formation. Appl. Environ. Microbiol. 2013, 79, 808-815. [CrossRef] [PubMed]

65. Leclère, V.; Béchet, M.; Adam, A.; Guez, J.-S.; Wathelet, B.; Ongena, M.; Thonart, P.; Gancel, F.; Chollet-Imbert, M.; Jacques, P. Mycosubtilin overproduction by Bacillus subtilis BBG100 enhances the organism's antagonistic and biocontrol activities. Appl. Environ. Microbiol. 2005, 71, 4577-4584. [CrossRef] [PubMed]

66. Mihalache, G.; Balaes, T.; Gostin, I.; Stefan, M.; Coutte, F.; Krier, F. Lipopeptides produced by Bacillus subtilis as new biocontrol products against fusariosis in ornamental plants. Environ. Sci. Pollut. Res. 2018, 25, 29784-29793. [CrossRef] [PubMed]

67. Radovanović, N.; Milutinović, M.; Mihajlovski, K.; Jović, J.; Nastasijević, B.; Rajilić-Stojanović, M.; Dimitrijević-Branković, S. Biocontrol and plant stimulating potential of novel strain Bacillus sp. PPM3 isolated from marine sediment. Microb. Pathog. 2018, 120, 71-78. [CrossRef]

68. Mizumoto, S.; Shoda, M. Medium optimization of antifungal lipopeptide, iturin A, production by Bacillus subtilis in solid-state fermentation by response surface methodology. Appl. Microbiol. Biotechn. 2007, 76, 101-108. [CrossRef]

69. Guevara-Avendaño, E.; Bravo-Castillo, K.R.; Monribot-Villanueva, J.L.; Kiel-Martínez, A.L.; Ramírez-Vázquez, M.; GuerreroAnalco, J.A.; Reverchon, F. Diffusible and volatile organic compounds produced by avocado rhizobacteria exhibit antifungal effects against Fusarium kuroshium. Braz. J. Microbiol. 2020, 51, 861-873. [CrossRef]

70. Guo, Q.; Dong, W.; Li, S.; Lu, X.; Wang, P.; Zhang, X.; Wang, Y.; Ma, P. Fengycin produced by Bacillus subtilis NCD-2 plays a major role in biocontrol of cotton seedling damping-off disease. Microbiol. Res. 2014, 169, 533-540. [CrossRef]

71. Nakayama, T.; Homma, Y.; Hashidoko, Y.; Mizutani, J.; Tahara, S. Possible role of xanthobaccins produced by Stenotrophomonas sp. strain SB-K88 in suppression of sugar beet damping-off disease. Appl. Environ. Microbiol. 1999, 65, 4334-4339. [CrossRef]

72. Milner, J.L.; Raffel, S.J.; Lethbridge, B.J.; Handelsman, J. Culture conditions that influence accumulation of zwittermicin A by Bacillus cereus UW85. Appl. Microbiol. Biotechnol. 1995, 43, 685-691. [CrossRef] 
73. Silo-Suh, L.A.; Lethbridge, B.J.; Raffel, S.J.; He, H.; Clardy, J.; Handelsman, J. Biological activities of two fungistatic antibiotics produced by Bacillus cereus UW85. Appl. Environ. Microbiol. 1994, 60, 2023-2030. [CrossRef] [PubMed]

74. Milner, J.L.; Silo-Suh, L.; Lee, J.C.; He, H.; Clardy, J.; Handelsman, J. Production of kanosamine by Bacillus cereus UW85. Appl. Environ. Microbiol. 1996, 62, 3061-3065. [CrossRef]

75. Gutiérrez-Román, M.I.; Holguín-Meléndez, F.; Bello-Mendoza, R.; Guillén-Navarro, K.; Dunn, M.F.; Huerta-Palacios, G. Production of prodigiosin and chitinases by tropical Serratia marcescens strains with potential to control plant pathogens. World J. Microbiol. Biotechnol. 2012, 28, 145-153. [CrossRef]

76. John Jimtha, C.; Jishma, P.; Sreelekha, S.; Chithra, S.; Radhakrishnan, E.K. Antifungal properties of prodigiosin producing rhizospheric Serratia sp. Rhizosphere 2017, 3, 105-108. [CrossRef]

77. Nielsen, T.H.; Sørensen, J. Production of cyclic lipopeptides by Pseudomonas fluorescens strains in bulk soil and in the sugar beet rhizosphere. Appl. Environ. Microbiol. 2003, 69, 861-868. [CrossRef]

78. Nielsen, T.H.; Sørensen, D.; Tobiasen, C.; Andersen, J.B.; Christophersen, C.; Givskov, M.; Sørensen, J. Antibiotic and biosurfactant properties of cyclic lipopeptides produced by fluorescent Pseudomonas spp. from the sugar beet rhizosphere. Appl. Environ. Microbiol. 2002, 68, 3416-3423. [CrossRef] [PubMed]

79. Raaijmakers, J.M.; Vlami, M.; de Souza, J.T. Antibiotic production by bacterial biocontrol agents. Antonie Leeuwenhoek 2002, 81, 537-547. [CrossRef]

80. Duffy, B.K.; Défago, G. Environmental factors modulating antibiotic and siderophore biosynthesis by Pseudomonas fluorescens biocontrol strains. Appl. Environ. Microbiol. 1999, 65, 2429-2438. [CrossRef] [PubMed]

81. Santoyo, G.; Urtis-Flores, C.A.; Loeza-Lara, P.D.; Orozco-Mosqueda, M.D.C.; Glick, B.R. Rhizosphere colonization determinants by plant growth-promoting rhizobacteria (PGPR). Biology 2021, 10, 475. [CrossRef]

82. Frankowski, J.; Lorito, M.; Scala, F.; Schmid, R.; Berg, G.; Bahl, H. Purification and properties of two chitinolytic enzymes of Serratia plymuthica HRO-C48. Arch. Microbiol. 2001, 176, 421-426. [CrossRef]

83. Fridlender, M.; Inbar, J.; Chet, I. Biological control of soilborne plant pathogens by a $\beta-1,3$ glucanase-producing Pseudomonas cepacia. Soil Biol. Biochem. 1993, 25, 1211-1221. [CrossRef]

84. Singh, P.P.; Shin, Y.C.; Park, C.S.; Chung, Y.R. Biological control of fusarium wilt of cucumber by chitinolytic bacteria. Phytopathology 1999, 89, 92-99. [CrossRef] [PubMed]

85. Kumar, P.; Dubey, R.C.; Maheshwari, D.K. Bacillus strains isolated from rhizosphere showed plant growth promoting and antagonistic activity against phytopathogens. Microbiol. Res. 2012, 167, 493-499. [CrossRef] [PubMed]

86. Martínez-Absalón, S.; Rojas-Solís, D.; Hernández-León, R.; Prieto-Barajas, C.; Orozco-Mosqueda, M.d.C.; Peña-Cabriales, J.J.; Sakuda, S.; Valencia-Cantero, E.; Santoyo, G. Potential use and mode of action of the new strain Bacillus thuringiensis UM96 for the biological control of the grey mould phytopathogen Botrytis cinerea. Biocontrol Sci. Technol. 2014, 24, 1349-1362. [CrossRef]

87. Ni, M.; Wu, Q.; Wang, J.; Liu, W.C.; Ren, J.H.; Zhang, D.P.; Zhao, J.; Liu, W.; Rao, Y.H.; Lu, C.G. Identification and comprehensive evaluation of a novel biocontrol agent Bacillus atrophaeus JZB120050. J. Environ. Sci. Health Part B 2018, 53, 777-785. [CrossRef] [PubMed]

88. Jamali, H.; Sharma, A. Biocontrol potential of Bacillus subtilis RH5 against sheath blight of rice caused by Rhizoctonia solani. J. Basic Microbiol. 2020, 60, 268-280. [CrossRef]

89. Naing, K.W.; Anees, M.; Kim, S.J.; Nam, Y.; Kim, Y.C.; Kim, K.Y. Characterization of antifungal activity of Paenibacillus ehimensis KWN38 against soilborne phytopathogenic fungi belonging to various taxonomic groups. Ann. Microbiol. 2014, 64, 55-63. [CrossRef]

90. Kamensky, M.; Ovadis, M.; Chet, I.; Chernin, L. Soil-borne strain IC14 of Serratia plymuthica with multiple mechanisms of antifungal activity provides biocontrol of Botrytis cinerea and Sclerotinia sclerotiorum diseases. Soil Biol. Biochem. 2003, 35, 323-331. [CrossRef]

91. Budi, S.W.; van Tuinen, D.; Arnould, C.; Dumas-Gaudot, E.; Gianinazzi-Pearson, V.; Gianinazzi, S. Hydrolytic enzyme activity of Paenibacillus sp. strain B2 and effects of the antagonistic bacterium on cell integrity of two soil-borne pathogenic fungi. Appl. Soil Ecol. 2000, 15, 191-199. [CrossRef]

92. Pieterse, C.M.J.; van Wees, S.C.M.; Ton, J.; van Pelt, J.A.; van Loon, L.C. Signalling in rhizobacteria-induced systemic resistance in Arabidopsis thaliana. Plant Biol. 2002, 4, 535-544. [CrossRef]

93. Zamioudis, C.; Pieterse, C.M. Modulation of host immunity by beneficial microbes. Mol. Plant Microbe Interact. 2012, 25, 139-150. [CrossRef]

94. Ramamoorthy, V.; Viswanathan, R.; Raguchander, T.; Prakasam, V.; Samiyappan, R. Induction of systemic resistance by plant growth promoting rhizobacteria in crop plants against pests and diseases. Crop. Prot. 2001, 20, 1-11. [CrossRef]

95. Pokhare, S.; Singh, P.; Shakil, N.A.; Kumar, J.; Singh, K. Foliar application of chemical elicitors induces biochemical changes in wheat against the cereal cyst nematode Heterodera avenae. Nematol. Medit. 2012, 40, 181-187.

96. De Vleesschauwer, D.; Höfte, M. Rhizobacteria-induced systemic resistance. Adv. Bot. Res. 2009, 51, $223-281$.

97. Kumar, A.; Gond, S.K.; Mishra, A.; Sharma, V.K.; Verma, S.K.; Singh, D.K.; Kumar, J.; Kharwar, R.N. Salicylic acid and its role in systemic resistance induced by Pseudomonas fluorescens to early blight disease of tomato. Int. J. Plant Res. 2015, $28,12-19$.

98. De Meyer, G.; Höfte, M. Salicylic acid produced by the rhizobacterium Pseudomonas aeruginosa 7NSK2 induces resistance to leaf infection by Botrytis cinerea on bean. Phytopathology 1997, 87, 588-593. [CrossRef] [PubMed] 
99. Iavicoli, A.; Boutet, E.; Buchala, A.; Métraux, J.P. Induced systemic resistance in Arabidopsis thaliana in response to root inoculation with Pseudomonas fluorescens CHA0. Mol. Plant Microbe Interact. 2003, 16, 851-858. [CrossRef]

100. Audenaert, K.; Pattery, T.; Cornelis, P.; Höfte, M. Induction of systemic resistance to Botrytis cinerea in tomato by Pseudomonas aeruginosa 7NSK2: Role of salicylic acid, pyochelin, and pyocyanin. Mol. Plant Microbe Interact. 2002, 15, 1147-1156. [CrossRef]

101. Ryu, C.-M.; Farag, M.A.; Hu, C.-H.; Reddy, M.S.; Kloepper, J.W.; Paré, P.W. Bacterial volatiles induce systemic resistance in Arabidopsis. Plant Physiol. 2004, 134, 1017-1026. [CrossRef] [PubMed]

102. Farag, M.A.; Ryu, C.-M.; Sumner, L.W.; Paré, P.W. GC-MS SPME profiling of rhizobacterial volatiles reveals prospective inducers of growth promotion and induced systemic resistance in plants. Phytochemistry 2006, 67, 2262-2268. [CrossRef] [PubMed]

103. Huang, C.-J.; Tsay, J.-F.; Chang, S.-Y.; Yang, H.-P.; Wu, W.-S.; Chen, C.-Y. Dimethyl disulfide is an induced systemic resistance elicitor produced by Bacillus cereus C1L. Pest. Manag. Sci. 2012, 68, 1306-1310. [CrossRef] [PubMed]

104. Schuhegger, R.; Ihring, A.; Gantner, S.; Bahnweg, G.; Knappe, C.; Vogg, G.; Hutzler, P.; Schmid, M.; Van Breusegem, F.; Eberl, L.; et al. Induction of systemic resistance in tomato by $\mathrm{N}$-acyl-L-homoserine lactone-producing rhizosphere bacteria. Plant Cell Environ. 2006, 29, 909-918. [CrossRef]

105. Pang, Y.; Liu, X.; Ma, Y.; Chernin, L.; Berg, G.; Gao, K. Induction of systemic resistance, root colonisation and biocontrol activities of the rhizospheric strain of Serratia plymuthica are dependent on $\mathrm{N}$-acyl homoserine lactones. Eur. J. Plant Pathol. 2009, 124, 261-268. [CrossRef]

106. Meziane, H.; van der Slis, I.; van Loon, L.C.; Höfte, M.; Bakker, P.A. Determinants of Pseudomonas putida WCS358 involved in inducing systemic resistance in plants. Mol. Plant Pathol. 2005, 6, 177-185. [CrossRef]

107. Kilic-Ekici, O.; Yuen, G.Y. Comparison of strains of Lysobacter enzymogenes and PGPR for induction of resistance against Bipolaris sorokiniana in tall fescue. Biol. Control 2004, 30, 446-455. [CrossRef]

108. Leeman, M.; van Pelt, J.A.; den Ouden, F.M.; Heinsbroek, M.; Bakker, P.A.H.M.; Schippers, B. Induction of systemic resistance by Pseudomonas fluorescens in radish cultivars differing in susceptibility to fusarium wilt, using a novel bioassay. Eur. J. Plant Pathol. 1995, 101, 655-664. [CrossRef]

109. Jetiyanon, K.; Kloepper, J.W. Mixtures of plant growth-promoting rhizobacteria for induction of systemic resistance against multiple plant diseases. Biol. Control 2002, 24, 285-291. [CrossRef]

110. Sharma, C.K.; Vishnoi, V.K.; Dubey, R.C.; Maheshwari, D.K. A twin rhizospheric bacterial consortium induces systemic resistance to a phytopathogen Macrophomina phaseolina in mung bean. Rhizosphere 2018, 5, 71-75. [CrossRef]

111. Sharma, S.; Mishra, A.K.; Dileep Kumar, B.S. Induction of systemic resistance against fusarial wilt in pigeon pea through interaction of plant growth promoting rhizobacteria and rhizobia. Soil Biol. Biochem. 2008, 40, 452-461.

112. Berendsen, R.L.; Vismans, G.; Yu, K.; Song, Y.; de Jonge, R.; Burgman, W.P.; Burmølle, M.; Herschend, J.; Bakker, P.; Pieterse, C.M.J. Disease-induced assemblage of a plant-beneficial bacterial consortium. ISME J. 2018, 12, 1496-1507. [CrossRef] [PubMed]

113. Dong, Y.H.; Gusti, A.R.; Zhang, Q.; Xu, J.L.; Zhang, L.H. Identification of quorum-quenching N-acyl homoserine lactonases from Bacillus species. Appl. Environ. Microbiol. 2002, 68, 1754-1759. [CrossRef] [PubMed]

114. Lin, Y.-H.; Xu, J.-L.; Hu, J.; Wang, L.-H.; Ong, S.L.; Leadbetter, J.R.; Zhang, L.-H. Acyl-homoserine lactone acylase from Ralstonia strain XJ12B: Ecological and evolutionary s of quorum-quenching enzymes. Mol. Microbiol. 2003, 47, 849-860. [CrossRef] [PubMed]

115. Han, Y.; Chen, F.; Li, N.; Zhu, B.; Li, X. Bacillus marcorestinctum sp. nov., a novel soil acylhomoserine lactone quorum-sensing signal quenching bacterium. Int. J. Mol. Sci. 2010, 11, 507-520. [CrossRef]

116. Mahmoudi, E.; Ebrahim, B.; Tabatabaei, S.; Venturi, V. Virulence attenuation of Pectobacterium carotovorum using N-Acylhomoserine lactone degrading bacteria isolated from potato rhizosphere. Plant Pathol. J. 2011, 27, 242-248. [CrossRef]

117. Park, S.Y.; Lee, S.J.; Oh, T.K.; Oh, J.W.; Koo, B.T.; Yum, D.Y.; Lee, J.K. AhlD, an N-acylhomoserine lactonase in Arthrobacter sp., and predicted homologues in other bacteria. Microbiology 2003, 149, 1541-1550. [CrossRef]

118. Fekete, A.; Kuttler, C.; Rothballer, M.; Hense, B.A.; Fischer, D.; Buddrus-Schiemann, K.; Lucio, M.; Müller, J.; Schmitt-Kopplin, P.; Hartmann, A. Dynamic regulation of $\mathrm{N}$-acyl-homoserine lactone production and degradation in Pseudomonas putida IsoF. FEMS Microbiol. Ecol. 2010, 72, 22-34. [CrossRef]

119. Huang, J.J.; Han, J.I.; Zhang, L.H.; Leadbetter, J.R. Utilization of acyl-homoserine lactone quorum signals for growth by a soil pseudomonad and Pseudomonas aeruginosa PAO1. Appl. Environ. Microbiol. 2003, 69, 5941-5949. [CrossRef]

120. Jayanna, S.K.; Umesha, S. Quorum quenching activity of rhizosphere bacteria against Ralstonia solanacearum. Rhizosphere 2017, 4, 22-24. [CrossRef]

121. Uroz, S.; D'Angelo-Picard, C.; Carlier, A.; Elasri, M.; Sicot, C.; Petit, A.; Oger, P.; Faure, D.; Dessaux, Y. Novel bacteria degrading $\mathrm{N}$-acylhomoserine lactones and their use as quenchers of quorum-sensing-regulated functions of plant-pathogenic bacteria. Microbiology 2003, 149, 1981-1989. [CrossRef]

122. Uroz, S.; Oger, P.; Chhabra, S.R.; Cámara, M.; Williams, P.; Dessaux, Y. N-acyl homoserine lactones are degraded via an amidolytic activity in Comamonas sp. strain D1. Arch. Microbiol. 2007, 187, 249-256. [CrossRef] [PubMed]

123. Kang, B.R.; Lee, J.H.; Ko, S.J.; Lee, Y.H.; Cha, J.S.; Cho, B.H.; Kim, Y.C. Degradation of acyl-homoserine lactone molecules by Acinetobacter sp. strain C1010. Can. J. Microbiol. 2004, 50, 935-941. [CrossRef] [PubMed]

124. Uroz, S.; Chhabra, S.R.; Cámara, M.; Williams, P.; Oger, P.; Dessaux, Y. N-Acylhomoserine lactone quorum-sensing molecules are modified and degraded by Rhodococcus erythropolis W2 by both amidolytic and novel oxidoreductase activities. Microbiology 2005, 151, 3313-3322. [CrossRef] 
125. Park, S.Y.; Kang, H.O.; Jang, H.S.; Lee, J.K.; Koo, B.T.; Yum, D.Y. Identification of extracellular N-acylhomoserine lactone acylase from a Streptomyces sp. and its application to quorum quenching. Appl. Environ. Microbiol. 2005, 71, 2632-2641. [CrossRef]

126. Park, S.Y.; Hwang, B.J.; Shin, M.H.; Kim, J.A.; Kim, H.K.; Lee, J.K. N-acylhomoserine lactonase producing Rhodococcus spp. with different AHL-degrading activities. FEMS Microbiol. Lett. 2006, 261, 102-108. [CrossRef] [PubMed]

127. Mei, G.Y.; Yan, X.X.; Turak, A.; Luo, Z.Q.; Zhang, L.Q. AidH, an alpha/beta-hydrolase fold family member from an Ochrobactrum sp. strain, is a novel $\mathrm{N}$-acylhomoserine lactonase. Appl. Environ. Microbiol. 2010, 76, 4933-4942. [CrossRef] [PubMed]

128. Wang, W.Z.; Morohoshi, T.; Ikenoya, M.; Someya, N.; Ikeda, T. AiiM, a novel class of N-acylhomoserine lactonase from the leaf-associated bacterium Microbacterium testaceum. Appl. Environ. Microbiol. 2010, 76, 2524-2530. [CrossRef]

129. Wang, W.Z.; Morohoshi, T.; Someya, N.; Ikeda, T. Diversity and distribution of $N$-acylhomoserine lactone (AHL)-degrading activity and AHL-lactonase (AiiM) in genus Microbacterium. Microbes Environ. 2012, 27, 330-333. [CrossRef] [PubMed]

130. Hanano, A.; Harba, M.; Al-Ali, M.; Ammouneh, H. Silencing of Erwinia amylovora sy69 AHL-quorum sensing by a Bacillus simplex AHL-inducible aiiA gene encoding a zinc-dependent $N$-acyl-homoserine lactonase. Plant Pathol. 2014, 63, 773-783. [CrossRef]

131. Berendsen, R.L.; Pieterse, C.M.J.; Bakker, P.A.H.M. The rhizosphere microbiome and plant health. Trends Plant Sci. 2012, 17, 478-486. [CrossRef]

132. Dunne, C.; Moenne-Loccoz, Y.; McCarthy, J.; Higgins, P.; Powell, J.; Dowling, D.N.; O'Gara, F. Combining proteolytic and phloroglucinol-producing bacteria for improved biocontrol of Pythium-mediated damping-off of sugar beet. Plant Pathol. 1998, 47, 299-307. [CrossRef]

133. Jetiyanon, K.; Fowler, W.D.; Kloepper, J.W. Broad-spectrum protection against several pathogens by PGPR mixtures under field conditions in Thailand. Plant Dis. 2003, 87, 1390-1394. [CrossRef]

134. Jetiyanon, K. Defensive-related enzyme response in plants treated with a mixture of Bacillus strains (IN937a and IN937b) against different pathogens. Biol. Control 2007, 42, 178-185. [CrossRef]

135. de Boer, M.; Bom, P.; Kindt, F.; Keurentjes, J.J.; van der Sluis, I.; van Loon, L.C.; Bakker, P.A. Control of Fusarium wilt of radish by combining Pseudomonas putida strains that have different disease-suppressive mechanisms. Phytopathology 2003, 93, 626-632. [CrossRef] [PubMed]

136. Kumar, H.; Dubey, R.C.; Maheshwari, D.K. Seed-coating fenugreek with Burkholderia rhizobacteria enhances yield in field trials and can combat Fusarium wilt. Rhizosphere 2017, 3, 92-99. [CrossRef]

137. Kumar, P.; Pandey, P.; Dubey, R.C.; Maheshwari, D.K. Bacteria consortium optimization improves nutrient uptake, nodulation, disease suppression and growth of the common bean (Phaseolus vulgaris) in both pot and field studies. Rhizosphere 2016, 2, 13-23. [CrossRef]

138. Lucas, J.A.; Ramos Solano, B.; Montes, F.; Ojeda, J.; Megias, M.; Gutierrez Mañero, F.J. Use of two PGPR strains in the integrated management of blast disease in rice (Oryza sativa) in Southern Spain. Field Crop. Res. 2009, 114, 404-410. [CrossRef]

139. Shanmugam, V.; Thakur, H.; Kaur, J.; Gupta, S.; Rajkumar, S.; Dohroo, N.P. Genetic diversity of Fusarium spp. inciting rhizome rot of ginger and its management by PGPR consortium in the western Himalayas. Biol. Control 2013, 66, 1-7. [CrossRef]

140. Bora, T.; Özaktan, H.; Göre, E.; Aslan, E. Biological control of Fusarium oxysporum f. sp. melonis by wettable powder formulations of the two strains of Pseudomonas putida. J. Phytopathol. 2004, 152, 471-475. [CrossRef]

141. Felici, C.; Vettori, L.; Giraldi, E.; Forino, L.M.C.; Toffanin, A.; Tagliasacchi, A.M.; Nuti, M. Single and co-inoculation of Bacillus subtilis and Azospirillum brasilense on Lycopersicon esculentum: Effects on plant growth and rhizosphere microbial community. Appl. Soil Ecol. 2008, 40, 260-270. [CrossRef]

142. Schmidt, C.S.; Agostini, F.; Simon, A.-m.; Whyte, J.; Townend, J.; Leifert, C.; Killham, K.; Mullins, C. Influence of soil type and pH on the colonisation of sugar beet seedlings by antagonistic Pseudomonas and Bacillus strains, and on their control of Pythium damping-off. Eur. J. Plant Pathol. 2004, 110, 1025-1046. [CrossRef]

143. Bardas, G.A.; Lagopodi, A.L.; Kadoglidou, K.; Tzavella-Klonari, K. Biological control of three Colletotrichum lindemuthianum races using Pseudomonas chlororaphis PCL1391 and Pseudomonas fluorescens WCS365. Biol. Control 2009, 49, 139-145. [CrossRef]

144. Castledine, M.; Padfield, D.; Buckling, A. Experimental (co)evolution in a multi-species microbial community results in local maladaptation. Ecol. Lett. 2020, 23, 1673-1681. [CrossRef] [PubMed]

145. Hubbard, J.P.; Harman, G.E.; Hadar, Y. Effect of soilborne Pseudomonas spp. on the biological control agent, Trichoderma hamatum, on pea seeds. Phytopathology 1983, 73, 655-659. [CrossRef]

146. Raaijmakers, J.M.; Sluis, L.v.d.; Bakker, P.A.H.M.; Schippers, B.; Koster, M.; Weisbeek, P.J. Utilization of heterologous siderophores and rhizosphere competence of fluorescent Pseudomonas spp. Can. J. Microbiol. 1995, 41, 126-135. [CrossRef]

147. Kragelund, L.; Nybroe, O. Competition between Pseudomonas fluorescens Ag1 and Alcaligenes eutrophus JMP134 (pJP4) during colonization of barley roots. FEMS Microbiol. Ecol. 1996, 20, 41-51. [CrossRef]

148. de Boer, M.; van der Sluis, I.; van Loon, L.C.; Bakker, P.A.H.M. Combining fluorescent Pseudomonas spp. strains to enhance suppression of fusarium wilt of radish. Eur. J. Plant Pathol. 1999, 105, 201-210. [CrossRef]

149. Molina, L.; Constantinescu, F.; Michel, L.; Reimmann, C.; Duffy, B.; Défago, G. Degradation of pathogen quorum-sensing molecules by soil bacteria: A preventive and curative biological control mechanism. FEMS Microbiol. Ecol. 2003, 45, 71-81. [CrossRef]

150. Manriquez, B.; Muller, D.; Prigent-Combaret, C. Experimental evolution in plant-microbe systems: A tool for deciphering the functioning and evolution of plant-associated microbial communities. Front. Microbiol. 2021, 12, 619122. [CrossRef] [PubMed] 
151. Loreau, M.; Hector, A. Partitioning selection and complementarity in biodiversity experiments. Nature 2001, 412, 72-76. [CrossRef] [PubMed]

152. Bell, T.; Newman, J.A.; Silverman, B.W.; Turner, S.L.; Lilley, A.K. The contribution of species richness and composition to bacterial services. Nature 2005, 436, 1157-1160. [CrossRef]

153. Stockwell, V.O.; Johnson, K.B.; Sugar, D.; Loper, J.E. Mechanistically compatible mixtures of bacterial antagonists improve biological control of fire blight of pear. Phytopathology 2011, 101, 113-123. [CrossRef]

154. Mundt, C.C. Use of multiline cultivars and cultivar mixtures for disease management. Annu. Rev. Phytopathol. 2002, 40, 381-410. [CrossRef] [PubMed]

155. LaMondia, J.A. Fungicide efficacy against Calonectria pseudonaviculata, causal agent of boxwood blight. Plant Dis. 2014, 98, 99-102 [CrossRef]

156. Wehner, J.; Antunes, P.M.; Powell, J.R.; Mazukatow, J.; Rillig, M.C. Plant pathogen protection by arbuscular mycorrhizas: A role for fungal diversity? Pedobiologia 2010, 53, 197-201. [CrossRef]

157. Agler, M.T.; Ruhe, J.; Kroll, S.; Morhenn, C.; Kim, S.T.; Weigel, D.; Kemen, E.M. Microbial hub taxa link host and abiotic factors to plant microbiome variation. PLoS Biol. 2016, 14, e1002352. [CrossRef] [PubMed]

158. Xu, X.; Robinson, J.; Jeger, M.; Jeffries, P. Using combinations of biocontrol agents to control Botrytis cinerea on strawberry leaves under fluctuating temperatures. Biocontrol Sci. Technol. 2010, 20, 359-373. [CrossRef]

159. Xu, X.M.; Salama, N.; Jeffries, P.; Jeger, M.J. Numerical studies of biocontrol efficacies of foliar plant pathogens in relation to the characteristics of a biocontrol agent. Phytopathology 2010, 100, 814-821. [CrossRef]

160. Xu, X.M.; Jeffries, P.; Pautasso, M.; Jeger, M.J. Combined use of biocontrol agents to manage plant diseases in theory and practice. Phytopathology 2011, 101, 1024-1031. [CrossRef] [PubMed]

161. Janisiewicz, W. Ecological diversity, niche overlap, and coexistence of antagonists used in developing mixtures for biocontrol of postharvest diseases of apples. Phytopathology 1996, 86, 473-479. [CrossRef]

162. Paredes, S.H.; Gao, T.; Law, T.F.; Finkel, O.M.; Mucyn, T.; Teixeira, P.J.P.L.; Salas González, I.; Feltcher, M.E.; Powers, M.J.; Shank, E.A.; et al. Design of synthetic bacterial communities for predictable plant phenotypes. PLoS Biol. 2018, 16, e2003962.

163. Huang, A.C.; Jiang, T.; Liu, Y.-X.; Bai, Y.-C.; Reed, J.; Qu, B.; Goossens, A.; Nützmann, H.-W.; Bai, Y.; Osbourn, A. A specialized metabolic network selectively modulates Arabidopsis root microbiota. Science 2019, 364, eaau6389. [CrossRef] [PubMed] 